\title{
Impoverishment of phonetic inventory or changes in phonetic inventory of the Italian-speaking population in Western Slavonia
}

\begin{abstract}
This paper focuses on sibilant and interdental fricative phones perceptible among reliable as well as all other types of speakers of the Italian Vernacular of Western Slavonia (IVWS). The production of fricatives in IVWS should be observed in relation to their presence in similar Italian dialectal vernaculars, namely in northern Veneto dialects, particularly in the archaic Belluno vernacular, and in western Friuli patois. The first research hypothesis is the proposition that a lack of correspondence in the pronunciation of certain phones can be treated as an expected phenomenon, due to the changes that the speech community has undergone. The second hypothesis is that the absence of some phones will be perceptible and consistent mostly among unreliable speakers and semi-speakers. The results show that the targeted phones exist in the pronunciation of mainly those speakers who have not been in contact with modern Italian variants; at the same time, the same phones are often substituted with near phones that exist in either modern Italian vernaculars or in the majority Croatian language.
\end{abstract}

\section{Introduction}

During the last few years, the isolated Italian community found in western Slavonia, whose origin is rather different from that of numerous Italian communities situated along the eastern Adriatic, has been discussed on several occasions (Deželjin 2015a, 2015b, 2015c, 2017a, 2017b). The community originated in 1879, when two Austro-Hungarian noblemen ${ }^{1}$ invited fifty families ${ }^{2}$ living in northern Veneto (Dolomiti region) along the river Piave in the vicinity of the

1 Northern Italians were known to be diligent people, and therefore, Josef Reiser and Philippe Stein, noblemen and merchants from Strižičevac, decided to sell small parcels of their land at a very convenient price to every Italian with valid documents (Brustolin 1997: 27).

2 Cf. document 5746/1880 deposited in box 433, kept in Croatian State Archives in Zagreb. 
town of Belluno to settle on their uninhabited land in Moslavina, specifically in the villages of Ploština, Kapetanovo Polje, Donja Obrijež, Banovac / Veliki Banovac, Badljevina, Filipovac, and Strižićevac. ${ }^{3}$ Several years later, new immigrants, from western Friuli and adjacent Veneto territories, arrived in Nova Gradiška and Požega, but then, during the first decade of the twentieth century, they moved to the village of Ciglenica, near Kutina. Despite their isolation in predominantly Croatian-speaking surroundings, ${ }^{4}$ these Italian-speaking communities stayed there and preserved their cultural characteristics and language. In the second half of the twentieth century, however, the Italian-speaking villages gradually grew smaller because their inhabitants started to move to other villages and towns in Croatia as well as in Italy. Today, only Ploština has a somewhat large and homogeneous cluster of Italian-speaking people. Some of the above-mentioned villages, such as Kapetanovo Polje, are empty today, while others, such as Veliki Banovac, Badljevina, and Strižičevac, have become mostly Croatian-speaking communities over the years.

In 1987, Adriana Savi described the vernacular of the Italian community in Ploština based upon the speech of five people from that village. During field research conducted between 2012 and 2017, I collected data from 52 informants. Analysing my recordings of their speech, I noticed that, in terms of their linguistic competence and pronunciation, my informants fell into three distinct speaker types: reliable speakers, unreliable speakers, and semi-speakers of the local Italian variety, which I call the Italian Vernacular of Western Slavonia (IVWS). Reliable speakers of IVWS, 5 most of whom live in Ploština, exhibit all the characteristics described by Savi (1987). The numerous unreliable speakers of IVWS fall into two distinct subgroups: one subgroup consists of those who, in their own opinion and self-estimation, exhibit perceivable difficulty when speaking their mother tongue because they do not use IVWS in their everyday communication but only on special occasions, since they live in prevalently Croatian-speaking communities. Their speech in IVWS can be inarticulate, full of empty pauses, auto-corrections, etc. The other subgroup consists of people who are (or were) professionally linked to northern Italy (mostly to the Belluno territory); their language is a vivid mixture of autochthonous IVWS and modern northern Italian vernaculars, although they are not aware of it. Semi-speakers of IVWS are people whose active exposure to IVWS stopped or grew weak in their youth. Semi-speakers' linguistic competence in IVWS is low and varies from acceptable to bad: some are able to express basic per-

3 The villages also have Italian names: Plostina, Campo del capitano (Kapetnovo Polje), Obrijez minore (Donja Obrijež), and Banovaz / Banovaz maggiore (Banovac/Veliki Banovac). Until 1910, the village of Ploština was known as Khuenovo Selo (after Ban Khuen Herdervary), and local people still use the old name.

4 My Italian-speaking informants remember that, in the past, numerous German- and Czech-speaking communities also lived in the same area.

5 All members of the Italian ethnic group in western Slavonia, regardless of their capacity to use IVWS, are fluent speakers of Croatian, the majority language of the region as well as the language of their education (Deželjin 2017a). 
sonal data using simple phrases and vocabulary, but many just remember certain words and expressions (Deželjin 2015a, 2015c).

Other works that discuss the same community (De Biasi 1995, Brustolin 1997, Kliček 2009, Pasanac et al. 2012) focus on historical, social, and cultural aspects of the Italian communities in Slavonia and include only superficial information about the local vernacular. All of them, including Savi (1987), disregard two facts: the distinct types of speakers and the limited number of reliable speakers. Moreover, although recent research and recordings have partially confirmed older observations concerning the pronunciation of some fricative phones (Savi 1987), it is obvious that the described phonetic peculiarities do not refer in a satisfactory way to the IVWS that is spoken today.

\section{The aim of this study}

One of the peculiarities mentioned in the description of the phonemic inventory and of its realization among speakers in Ploština (Savi 1987: 11, 12) is the status of sibilant fricatives. Savi points out that both /s/ and /z/ can be realized as voiceless and voiced alveolar, postalveolar (or prepalatal), and alveolo-palatal (or mediopalatal) fricative phones, i.e. the unvoiced series $\left[s, \int, 6\right]$ and the voiced series $[z, 3, z] .6$ She affirms that an Italian voiceless or voiced alveolar sibilant will be always realized as either postalveolar or alveolo-palatal in IVWS, and that the choice between the two possibilities is up to the speaker. The freedom to pronounce /s/ as either [J] or [6] and /z/ as [3] or [z] leads to phonetic doublets of certain words in this variety (Savi 1987: 12). Another important issue is that of two interdental fricatives, the phoneme $/ \theta /$ and the allophone $[\delta]$ (as a variant of $/ \mathrm{d} /$ ), and of a particular phone $t \theta$, which, according to Savi (1987: 16) once probably was also a phoneme, and whose pronunciation can be achieved if a plosive is pronounced immediately before the pronunciation of $\theta .{ }^{7}$ Since recent recordings have not confirmed all of the above-mentioned sound, I made additional recordings in order to check the presence of the targeted phones among reliable as well as all other types of speakers, but also to understand what kinds of changes have occurred and what has caused them. The first hypothesis of this study is the proposition that a lack of correspondence in the pronunciation of certain fricatives (sibilants and non-sibilants), or even their absence, can be treated as an expected phenomenon, due to the changes that the speech community underwent over a period of thirty years. The second hypothesis is that the absence of some phones will be perceptible and consistent mostly among unreliable speakers and semi-speakers.

6 Savi (1987) uses traditional transcription to represent these phones in her work. The voiceless series is represented as [s, š, ś] and the voiced one as [z, ž, ź].

7 Describing the articulation of this phone, the author specifies that the tongue must be placed between teeth so that it can touch them with greater mass than when pronouncing the other two interdental fricatives, (Savi 1987: 13). 


\section{Subjects and methodology}

A total of 12 subjects (seven women and five men) of varying levels of linguistic competence consented to take part in the new recordings. These included four reliable 8 speakers ( 1 male and 2 females from Ploština and one female from Lipik; four unreliable speakers (three males and one female); and four semi-speakers ${ }^{9}$ (three females, from Brekinska, Lipik, and Strižičevac, and one male from Kutina). Among the four unreliable speakers, two males (from Ploštine and Obrijež) have intense and active contacts with northern Veneto, particularly the Belluno region, while the other two, from Ciglenica, do not have such linguistic experiences. The selected subjects are suitable as informants because they have two important characteristics in common: age and education. All the reliable speakers, two of the unreliable speakers, and one semi-speaker are older than 75 years of age, while two unreliable speakers and three semi-speakers are aged between 58 and 70 . All of the reliable speakers and semi-speakers have elementary education and earned their living as farmers or homemakers, while the unreliable speakers and one semi-speaker finished high school and worked in industry or as shop assistants).

Based on the already existing recordings and taking into account the heterogeneous linguistic competence of these subjects, I composed a list of words, mostly known even to my semi-speakers, divided into three groups according to the targeted phones. The first two groups include words typically pronounced with [s] in Italian (Table1), whose equivalents in IVWS can be pronounced as either [S] or [6], and words pronounced with its voiced pair, [z], in Italian (Table 2), which in IVWS is realized as [3] or [z]. There were eleven items in the first group and ten in the second one. I expected that, in the given set of words, every speaker would realize the targeted sibilant differently in word-initial position than when it appears within a word. The third group consisted of interdental fricatives (Savi 1987), a voiceless $[\theta]$, a voiced $[\delta]$ and the $[t \theta]$ phone. There were fifteen words (five per each phone) in this group (Table 3), and each phone was placed at the beginning of the word or within it. The subjects were asked to pronounce each isolated word in IVSW10, said

A reliable speaker, as defined also in Deželjin 2015c, has got high communicative competence in IVWS; this language variety, used fluently and daily, corresponds to that described in Savi (1987) and its lexical repertoire can be found in the relevant dictionaries (Lancerini 1993, Tomasi 1983).

9 A category of semi-speakers embraces people of modest or hardly ever linguistic competence in IVWS because they ceased to use their mother tongue in youth since they had moved into a Croatian speaking community (Deželjin 2015c).

10 The Italian words containing a voiceless sibilant are as follows: testa, stalla, scalino, basso, susina, aspettare, salame, bosco, soffitta, sano, scuola (respectively, 'head, stable, stair, low, plum, to wait, salami, woods, attic, healthy, school'). The words with a voiced sibilant are as follows: casa, viso, muso, svelto, piseli (the IVWS equivalent is bizi), susina, naso, riso, chiesa, sposato (respectively, 'house, face, muzzle, bright, peas, plum, nose, rice, church, married'). The last item in this series was useful also as a word containing allophones of $/ \mathrm{s} /$. The words with interdental phones are as follows: $\theta$ - bicchiere (the equivalent is go $\theta$ ), cipola (i.e. $\theta$ eule), braccio, cinque, cento (respectively, 'glass, onion, arm, five, hundred'); $\delta$ - dormire, genero, vuoto, guardare, piangere (respectively, 'to sleep, son-in-law, empty, to watch, to cry'), and $t \theta$ - zucca, zucchero, cesta, cena (respectively, 'pumpkin, sugar, basket, supper'). Since we are discussing the pronunciation of sounds, all recorded words, as well as those that are quoted as the examples in literature, will be written in italic letters instead of being put in square brackets. 
previously by the researcher in Croatian and/or in Italian, and then to form a simple sentence with each word, if possible. Every time, if necessary, the semi-speakers were helped by the researcher during the first part of the task: the researcher would suggest the initial part of the word to enable a person to remember it. However, none of them remembered two words containing the voiced sibilant and one word with the $[\mathrm{t} \theta]$ phone, so that my results, concerning these informants, refer only to eight items with the voiced sibilant and four items with the interdental fricative [ $t \theta$ ]. These subjects also failed to accomplish the second part of the task.

The experiment was carried out on several occasions, during the field research in Pakrac (2016), in Lipik and its surroundings and in Kutina and its surroundings (2017) and in Ploština (2016 and 2018). The recordings were made with the help of a digital recorder. Concerning the age of my informants and very often also their poor health, the only possible place to make recordings was in a familiar environment. Since there was not much choice, six recordings were made in the informant's kitchen, three in the informant's yard and three in a meadow. As one may assume, these recording conditions were far from that which a researcher would desire, because I had to do all necessary activities by myself: pronounce the targeted words, pay attention to the subject while pronouncing the same words so that s/ he would not be distracted, pay attention to other people present in the room so that they would keep their voices down or would not comment on the person being recorded, control the digital recorder and so on. Under such circumstances, it was impossible to control the amount of noise, which was rather high, even when the recordings were carried out in the house, because there were always other people present in the same or in the adjacent room, who were talking, performing some activity, listening to music etc. Apart from that, due to poor window insulation, it was also very difficult to avoid or at least lower the noise coming from the outside, and the same problem was multiplied when I had to record in the open (dogs barking, birds chirping, tractors and cars passing by, etc.).

The field recordings were recorded directly onto a computer. Since I was interested in fricative ${ }^{11}$ phones, I tried to use the LPC peak-picking analysis and single gravity centre measures. However, I had to give it up, mostly because of numerous formants. Taking into account the subjects' age and dental status, which always influences a speaker's production, as well as the background noise, which was considerable, I decided to entrust the analysis of the recordings to the perception of three trained and three untrained listeners. The audio recordings were listened to twice so that the phones in question could be analysed and described properly, especially concerning their place of articulation.

11 Fricatives are not easy to describe by their formant frequencies: "different types of fricatives have different features that are important in their auditory perception. For sibilant fricatives such as $\mathbf{s}$ and $\boldsymbol{\int}$, the most important attributes may be the lower edge of the spectrum and the center frequencies of the peaks in the spectrum" (Ladefoged 2007: 155). However, these properties are not easy to measure precisely. 
The analysis was carried out on a corpus of 418 words which were pronounced as isolated. Among these, there were 132 items that in Italian would be pronounced with [s], while in IVWS [J] or [6] are possible, 120 items that would contain [z] in Italian, whereas in IVWS [3] or [z] are possible. As for the fricative phones, there were 60 items in which, according to Savi (1987), [ $\theta$ ] was expected, 60 items in which $[\delta]$ was expected and finally 60 items in which the phone [t $\theta]$ was expected. Apart from these data, trained and untrained listeners analysed the quality of the targeted phones in 248 short sentences produced by reliable and unreliable speakers: 88 items containing a word with a voiceless fricative sibilant, 80 with a voiced fricative sibilant and then 80 sentences in which $[\theta]$, [ $\delta]$ and $[\mathrm{t} \theta]$ were expected.

\section{Fricatives in IVWS and in similar Italian ${ }^{12}$ dialectal vernaculars}

The production of fricatives in IVWS should be observed in relation to their presence in similar Italian dialectal vernaculars, namely in the archaic Belluno vernacular (illustrated by Tomasi 1983), in the Basso Cismon vernacular (described by Lancerini 1993), and in western Friuli patois.

In many Italian dialects, $s-$ in initial position and $s$ in consonant clusters ( $s p$, $s t$, sk) in medial position, easily becomes ${ }^{13}$ (Rohlfs 1966: 224-226, 379). As for the sequence si, particularly outside the Tuscan area, Rohlfs ${ }^{14}$ (1966: 407) claims that in northern Italy it changes to $\int$, but sometimes also to $3^{15}$ or to $z^{16}$, the latter being the only possibility in Veneto and especially in Venice (Zamboni 1988). The Latin sequences GE-, GI- in initial position changed to $z$ in many northern Italian dialects, (Rohlfs 1966: 210). In some northern ${ }^{17}$ Italian vernaculars, and thus also in parts of northern Veneto, $s$, and less frequently $z$, can be somewhat palatalized 18 , particularly if its production is due to the tongue position, as it is in western Friu-

12 As Sorianello says (2002: 27): "La lingua italiana possiede tre serie di suoni fricativi: labiodentali /f v/, alveolari /s z/, postalveolare / $/$; quest'ultima serie è incompleta poiché la corrispondente sonora è assente, per lo meno nel cosiddetto italiano standard“, specifying that „[3] è presente nell'italiano toscano, dove rappresenta la variante $\mathrm{di} / \mathrm{d} 3 /$ in contesto intervocalico". (There are three series of fricative phones in the Italian

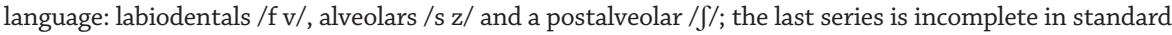
Italian, but its voiced pair, [3], is possible in Tuscan vernaculars as a variant of [d]] between vowels.).

13 In this paper the IPA symbols are used and therefore all other symbols, used by the authors that are largely quoted here, will be changed into those common nowadays.

14 All quoted examples will be reproduced faithfully and this means that the orthographic form of an example reflects its pronunciation.

15 Rohlfs (1966: 407) cites examples with [3] in the Liguria dialects ("bazà, bazu, fazö", 'fagiuoli'), in northern Piemont vernaculars (“bazà", baciato, 'kissed').

16 Rohlfs (1966: 407) cites the following examples: "bazo, bazar, tamizo, bruzar, fazolo".

17 Rosalio (1979: 15-17) analysed the speech of descendants of Italian settlers from Trentino living today in Štivor (Bosnia and Herzegovina) and noted the postalveolar sibilants [J] and [3] in their vernacular.

18 Zamboni reports of the presence of ś in rural vernaculars of the Verona dialect (1974: 46-47). 
$\mathrm{li}^{19}$ vernaculars. However, the phenomenon $s-\int-6$ is best perceived in the central part of Friuli, east of the Tagliamento river, and in the northern parts of the region (Francescato 1962: 55).20 Quite a similar situation also concerns voiced sibilants, 21 although different phonetic realizations in that case did not lead to phonological oppositions, and it can be said that / $z$ / has two allophones, [z] and [3], in complementary distribution, and that [3] often leads to [z], even though Francescato is not explicit about this element.

Savi (1987:16) mentions the three interdental phones, $\delta$, $\theta$, and $t \theta^{22}$, claiming that $[\delta]$ is a phonic variant of $/ \mathrm{d} / 23,[\theta]$ could perhaps be treated as a phoneme $/ \theta /$, while $[\mathrm{t} \theta$ ] most probably is a separate phoneme $/ \mathrm{t} \theta /$. Zamboni (1974: 37 ) says that interdental phones can be traced in a large territory that starts with a VenetoFriulan amfizona in the eastern Veneto, goes westward toward Belluno and Feltre, where these phones are abundantly present, and ends in the area of Ladin vernaculars in the Alps. In northern Italian vernaculars, and in particular in those areas that are relevant for this research, i.e., in some parts of central and northern Veneto (Zamboni 1974: 36-37, 52) and in a greater part of Friuli, the interdental voiceless fricative is present only as a further stage in the evolution of $t s(<\mathrm{CE}, \mathrm{CI})$ in initial position (Rohlfs 1966: 202). ${ }^{24}$ As for $\delta$, Rohlfs (1966: 274) speaks of its presence in northern Italian dialects in the transitional phase concerning the evolution of the Latin suffix -ATUM ( $>a d o>a \delta>a)$. Disregarding its occurrence in southern Italian dialects (Rohlfs 1966: 295-296), $\delta$ can also be the outcome of the evolution of Latin GE-, GI- in initial position, as is the case in the Belluno area, where the forms Senaro (genero 'son-in-law'), delar (gelare 'to freeze', Rohlfs 1966. 210) correspond to those noticed in IVWS.

19 Francescato explains that there are three different types of realization that could stand for $/ \mathrm{s} /$ and $/ \mathrm{z} /$ at the level of the norm. According to the position of tongue, these possibilities regarding $/ \mathrm{s} /$ are: $1 \mathrm{st}$ type: $/ \mathrm{s} /=[\mathrm{s}]$, $/ \mathrm{J} /=[\mathrm{J}] ;$ 2nd type: $/ \mathrm{s} /=[\mathrm{s}], / \mathrm{J} /=[\mathrm{c}] ; 3 \mathrm{rd}$ type: $/ \mathrm{s} /=[\mathrm{c}], / \mathrm{J} /=[\mathrm{J}]$ ", (Francescato 1962: 57).

20 Yet, in the area west of the Tagliamento river, the same numerous combinations and different realizations of sibilant sounds that are present in the north cannot be found. Only the phoneme /s/, in fact, as a result of the fusion of Latin $s$ in all cases (which continue the Latin sound) and of those obtained through the developing processes of $\mathrm{CE}$ and $\mathrm{CI}$ (at the end of the word after a consonant), can be found in that zone. Therefore, Francescato (1962: 62) qualifies this part of the Friuli area as innovative, compared to the conservative, northern part.

21 Even though the distribution and realization of voiceless alveolars, prepalatals, and mediopalatals has been described in more detail, the same principle is also valid for their voiced pairs, i.e. $z, 3$, and $z$. (Francescato 1962: 66-67).

22 Interdental phones, whose quality may vary, can be perceived in the vernacular spoken by descendants of immigrants from Trentino who settled in the present-day village of Štivor in Bosnia and Herzegovina (Rosalio 1979: 75-76, 83).

23 Savi argues that there are several examples of verbal syntagms to back up this hypothesis. Namely, this interdental phone can be perceived between vowels, either in contact position between two morphemes or words

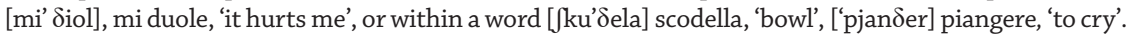

24 When $\theta$ loses its occlusion, the last stage of the evolution is $s$, which has spread to most northern Italian dialects (Zamboni 1974: 36). 


\section{Analysis of results}

\subsection{Voiceless sibilants}

\begin{tabular}{|c|c|c|c|c|c|c|c|c|c|c|c|c|}
\hline $\begin{array}{c}\text { subjects } \\
\text { reliable }\end{array}$ & 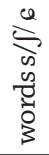 & $\stackrel{\mathbb{J}}{\mathbb{D}}$ & $\frac{\pi}{\widetilde{7}}$ & 寻 & $\begin{array}{l}0 \\
\& \\
\text { శ్ } \\
\text { తి }\end{array}$ & 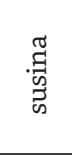 & 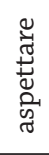 & $\begin{array}{l}\text { ๕్ } \\
\text { శ్ } \\
\text { శ్ }\end{array}$ & $\begin{array}{l}\stackrel{\cup}{0} \\
8 \\
8\end{array}$ & 胥 & 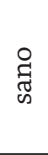 & 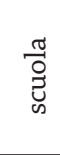 \\
\hline & 1 & 6 & $\int$ & 6 & 6 & 6 & 6 & 6 & 6 & 6 & 6 & 6 \\
\hline & 2 & $\int / / 6$ & 6 & 6 & 6 & 6 & 6 & 6 & $\int / / 6$ & $\int / / 6$ & $\int$ & $\int$ \\
\hline & 3 & 6 & 6 & 6 & 6 & 6 & 6 & 6 & 6 & 6 & 6 & 6 \\
\hline & 4 & $\int$ & $\int / / 6$ & $\int$ & 6 & 6 & 6 & 6 & $\int$ & $\int$ & 6 & $\int$ \\
\hline \multicolumn{13}{|c|}{ unreliable } \\
\hline & 1 & $\mathrm{~s}$ & 6 & $s$ & 6 & 6 & 6 & $\mathrm{~s}$ & $s$ & $s$ & $\mathrm{~s}$ & $6 / / \int$ \\
\hline & 2 & $\mathrm{~s}$ & $s$ & $s$ & $s$ & $6 / / \int$ & $\mathrm{s}$ & $\mathrm{s}$ & $s$ & $s$ & $s$ & $s$ \\
\hline & 3 & 6 & $\int$ & 6 & $\mathrm{~s}$ & 6 & $\mathrm{~s}$ & $s$ & $\int$ & $\int$ & 6 & $\mathrm{~s}$ \\
\hline & 4 & 6 & $\int$ & 6 & $\mathrm{~s}$ & 6 & $\int$ & $\mathrm{s}$ & $\int$ & $\int$ & $\int$ & $\int$ \\
\hline \multicolumn{13}{|c|}{ semi-speakers } \\
\hline & 1 & $\int$ & $\int$ & $\int$ & $\int$ & $\int$ & $\int$ & $s$ & $\int$ & $\int$ & $\int$ & 6 \\
\hline & 2 & $\int$ & $\int$ & $\int$ & $\int$ & $\int$ & $\int$ & $\mathrm{s}$ & $\int$ & $\int$ & $\int$ & $\int$ \\
\hline & 3 & $\int$ & $\int$ & $\int$ & $\int$ & $\int$ & $\int$ & $s$ & $\int$ & $\int$ & $\int$ & 6 \\
\hline & 4 & $\int$ & $\int$ & $\int$ & $\int$ & $\int$ & $\int$ & $\mathrm{s}$ & $\int$ & $\int$ & $\int$ & $\int$ \\
\hline
\end{tabular}

Table 1. Variation in the pronunciation of voiceless sibilants

According to the perception of trained and untrained listeners, in the speech of reliable IVWS speakers, the sibilant 6 prevails (see Table 1). One reliable female speaker always pronounces the equivalent of Italian /s/ as 6 , while a reliable male pronounces it in $90.9 \%$, and as fonly in /tala 25 (stalla, 'stable') in all situations. On the other hand, two female subjects vary between $\int$ and 6 . One of them produces the former phone in isolated words (te/ta, bo/k, fofit, fan, fkola) and the latter when the same words are contextualised ${ }^{26}$ (tecta, bock, 6ofit, 6an, 6kola), while in the other 6 words only 6 is heard. Another reliable speaker pronounces five words with $\int$ in both contexts (te/ta, Jkalin, bofk, fofit, Jkola) and five (45.5\%) with 6 (ba6, 6uzin, cpetar, calame, 6 an), while the eleventh word (9.1\%) is heard as Jtala when pronounced in isolation but as ctala within a sentence.

Two unreliable male speakers exposed to northern Venetian vernaculars pronounce the Italian /s/ as 6 only in the word 6 uzin when isolated, since one of them pronounces the same word with $\int$ ( Juzin) when it is part of a sentence. The same subject pronounces all other words with s (testa, stala, skalin, bas, spetar, salame, bosk, sofita, san, skola), which shows that his pronunciation is equivalent to Italian and Belluno pronunciation. The other male subject lives in Ploštine surrounded by 
speakers of IVWS, and, despite his occasional contacts with Italians in Italy, pronounces $36.4 \%$ of the words, either isolated or not, with 6 (6tala, ba6, cuzin, 6petar), while oscillation between $\int$ and 6 is perceived only in one word: /kola, when isolated, and ckola within a phrase.

The other two unreliable speakers, who are not exposed to the influence of the Italian language or its vernaculars, pronounce most of the words from the list, whether isolated or contextualised, in the same way ${ }^{27}$ : in three of them 6 is heard (tecta, ckalin and 6uzin), in another three $\int$ is perceived (ftala, bo/k, and fofit), and $s$ occurs in bas and salame. ${ }^{28}$ Three words are pronounced differently by these subjects in both contexts: the male always says spetar and skola, while the female says Jpetar and/kola; the male always says 6 an, and the female says Jan/a.

The phone $\int$ prevails in the speech of the four semi-speakers, who pronounce $81.8 \%$ of the words on the list as follows: te/ta, Jtala, Jkalin, baf, Juzin, Jpetar, bo/k, fofit, and fan. 29 The phone $s$ is heard in salame, and oscillation between 6 and $\int$ was perceived only in ckola / Jkola.

The results show that in a corpus of 264 words (see Table 2), 6 was present in 96 items (36.36\%), mostly in the reliable subjects' pronunciation, while $\int$ appeared in 117 items (43.56\%), pronounced mostly by semi-speakers. The presence of $s$ (53 items, 20.08) is characteristic mostly of the unreliable speakers who have contacts with northern Italian vernaculars.

\begin{tabular}{|l|c|c|c|}
\hline subjects reliable & $\int$ & 6 & $s$ \\
\hline & 20 & 2 & 0 \\
\hline & 15 & 7 & 0 \\
\hline & 22 & 0 & 0 \\
\hline unreliable & 11 & 11 & 13 \\
\hline & 9 & 0 & 20 \\
\hline & 1 & 1 & 8 \\
\hline semi-speakers & 8 & 6 & 4 \\
\hline & 6 & 12 & 2 \\
\hline & 2 & 18 & 2 \\
\hline & 0 & 20 & 2 \\
\hline & 2 & 18 & 2 \\
\hline tot. item. & 0 & 20 & 53,00 \\
\hline & 96,00 & 115,00 & $20,08 \%$ \\
\hline
\end{tabular}

Table 2. Number of items per speaker pronounced with a voiceless sibilant

27 It might be of some importance that these subjects are spouses.

28 The Croatian influence for the pronunciation salame is possible in this case as well.

29 As these subjects were not able to form a simple sentence with every word, they were asked to pronounce the same word several times, but never repeatedly. 


\subsection{Voiced sibilants}

\begin{tabular}{|c|c|c|c|c|c|c|c|c|c|c|c|}
\hline $\begin{array}{l}\text { subjects } \\
\text { reliable }\end{array}$ & 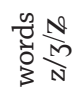 & 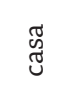 & $\begin{array}{l}0 \\
.9 \\
5 \\
5\end{array}$ & $\begin{array}{l}0 \\
\text { : } \\
\text { : }\end{array}$ & 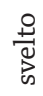 & 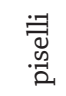 & 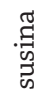 & $\begin{array}{l}\text { O } \\
\text { đ్ }\end{array}$ & 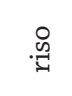 & 鸪 & $\begin{array}{l}\tilde{w} \\
0 \\
0 \\
\text { की }\end{array}$ \\
\hline & 1 & Z & Z & z & 3 & 3 & Z & Z & Z & Z & z \\
\hline & 2 & z & z & z & 3 & 3 & z & $\mathrm{z} / / 3$ & Z & Z & z \\
\hline & 3 & z & z & z & 3 & 3 & z & z & z & Z & z \\
\hline & 4 & Z & z & $\mathrm{z}$ & 3 & 3 & $\mathrm{Z}$ & Z & $\mathrm{z} / / 3$ & Z & z \\
\hline \multicolumn{12}{|c|}{ unreliable } \\
\hline & 1 & $\mathrm{z} / / \mathrm{z}$ & $\mathrm{z} / / \mathrm{z}$ & z & $\mathrm{z}$ & 3 & 3 & $\mathrm{z}$ & z & $\mathrm{z}$ & $\mathrm{z}$ \\
\hline & 2 & $\mathrm{z}$ & $\mathrm{z}$ & $\mathrm{z}$ & $z$ & $6 / / \int$ & 3 & z & $\mathrm{z}$ & $\mathrm{z}$ & $\mathrm{z}$ \\
\hline & 3 & Z & Z & Z & 3 & $3 / / 2$ & 3 & $z / / z$ & 3 & Z & Z \\
\hline & 4 & $\mathrm{Z}$ & $\mathrm{Z}$ & Z & 3 & 3 & 3 & $\mathrm{z}$ & 3 & Z & z \\
\hline \multicolumn{12}{|c|}{ semi-speakers } \\
\hline & 1 & 3 & 0 & 3 & 0 & 3 & 3 & Z & 3 & 3 & $\mathrm{z} / / 3$ \\
\hline & 2 & 3 & 0 & $\mathrm{z} / / 3$ & 0 & 3 & 3 & $\mathrm{z} / / 3$ & 3 & 3 & $\mathrm{z} / / 3$ \\
\hline & 3 & 3 & 0 & z//3 & 0 & 3 & 3 & 3 & 3 & 3 & 3 \\
\hline & 4 & 3 & 0 & $\mathrm{z} / / 3$ & 0 & 3 & 3 & $\mathrm{z} / / / 3$ & 3 & 3 & $\mathrm{z} / / \mathrm{s}$ \\
\hline
\end{tabular}

Table 3. Variation in the pronunciation of voiced sibilants

All reliable speakers pronounce five words with $z$ in both situations ( $k a z a, v i z o$, muzo 6uzin, and $6 \mathrm{poza} / \mathrm{t}$ ), and two words with 3 (zvelto, bizi). Oscillations between 3 and $z$ are perceived in two words (see Table 3 ). Two females realize the phone $z$ if the word is isolated, so that one says naz and another riz, but 3 is heard if these words are contextualised. Finally, one female subject always says tfeza.

The prevalence of $z$ in the pronunciation of unreliable speakers with active language contacts in Italy, observed in five words in both contexts, is not surprising (muz, zvelto, naz, tfeza/kjeza, 30 and $6 /$ spoza $(t)$ ), while 3 was heard in two words, pronounced either isolated or contextualized: (bizi, $6 /$ fuzin). There are only two cases in which an informant pronounces a voiced sibilant differently depending on whether it was isolated or contextualized: one younger male subject pronounces the phoneme as $\mathrm{z}$ when the word is isolated ( $k a z a, v i z)$ and as $\mathrm{z}$ when it is in a sentence (kaza, viz).

30 One of these subjects pronounces the Italian variant of the word, i.e. [kjeza], instead of the dialectal form [teza]. 
The pronunciation of the two unreliable speakers without active language contacts in Italy is identical to that of reliable speakers for seven words: in five words, $z$ is heard ( $k a z a, v i z, m u z, t e z a, s p o z a)$, and in two, $z$ is perceived (zvelto, bizi). The phone 3 is heard in two words, cuzin and riz, which are pronounced with $z$ by reliable speakers. Variation between $\mathrm{z}$ and $\mathrm{z}$ is observed in the speech of one subject in the word naz/z.

Semi-speakers ${ }^{31}$ pronounced eight words familiar to them (and that would be 100\%) with 3 . However, since I asked these subjects to repeat the words they knew several times, there are three words in the recordings in which semi-speakers oscillate between $z$ and 3 : /pozà //pozà, muz/muz and naz/naz.

Summing up the presented data, it is clear that $z$ slightly prevails over 3 , since the former was heard in 110 out of 232 items, or in $47.41 \%$ of the items, while the latter is present in 93 items (40.09\%). We also note the presence of $z$ in 29 items (12.58\%), pronounced mostly by the unreliable speakers exposed to northern Italian vernaculars and Italian neo-standard varieties.

\begin{tabular}{|l|c|c|c|}
\hline subjects reliable & $\mathrm{z}$ & 3 & $\mathrm{z}$ \\
\hline & 16 & 4 & 0 \\
\hline & 15 & 5 & 0 \\
\hline & 16 & 3 & 0 \\
\hline unreliable & 15 & & 12 \\
\hline & 14 & 4 & 16 \\
\hline & 0 & 7 & 1 \\
\hline & 12 & 8 & 0 \\
\hline semi-speakers & 12 & & 0 \\
\hline & 3 & 13 & 0 \\
\hline & 3 & 13 & 0 \\
\hline & 1 & 15 & 0 \\
\hline & 3 & 13 & 29,00 \\
\hline tot. item. & 110,00 & 93,00 & $12,50 \%$ \\
\hline & $47,41 \%$ & $40,09 \%$ & \\
\hline
\end{tabular}

Table 4. Number of items per speaker pronounced with a voiced sibilant

31 These subjects did not repeat or pronounce the words svelto and viso, which this means that these words do not exist in their lexicon anymore. 


\subsection{Interdental fricatives}

\begin{tabular}{|c|c|c|c|c|c|c|c|c|c|c|c|c|c|c|c|}
\hline $\begin{array}{l}\text { subjects } \\
\text { reliable }\end{array}$ & $\begin{array}{l}0 \\
0 \\
0 \\
3\end{array}$ & 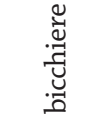 & 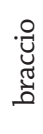 & 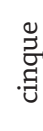 & 苞 & 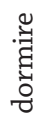 & 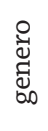 & $\begin{array}{l}\stackrel{2}{0} \\
\vdots\end{array}$ & 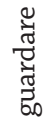 & 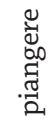 & 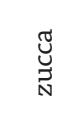 & 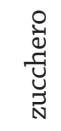 & 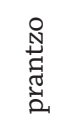 & 胥 & 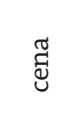 \\
\hline & 1 & $\theta$ & $\theta$ & $\theta$ & $\theta$ & $\delta$ & $\delta$ & $\delta$ & $\delta$ & $\delta$ & $\mathrm{t} \theta$ & $\mathrm{t} \theta$ & $\mathrm{t} \theta$ & $\mathrm{t} \theta$ & $\mathrm{t} \theta$ \\
\hline & 2 & $\theta$ & $\theta$ & $\theta$ & $\theta$ & $\delta$ & $\delta$ & $\delta$ & $\delta$ & $\delta$ & $\mathrm{t} \theta$ & $\mathrm{t} \theta / \theta$ & $\mathrm{t} \theta / \theta$ & $\mathrm{t} \theta$ & $\mathrm{t} \theta / \theta$ \\
\hline & 3 & $\theta$ & $\theta$ & $\theta$ & $\theta$ & $\delta$ & $\delta$ & $\delta$ & $\delta$ & $\delta$ & $\mathrm{t} \theta$ & $\mathrm{t} \theta / \theta$ & $\mathrm{t} \theta$ & $\mathrm{t} \theta$ & $\mathrm{t} \theta$ \\
\hline & 4 & $\theta$ & $\theta$ & $\theta$ & $\theta$ & $\delta$ & $\delta$ & $\delta$ & $\delta$ & $\delta$ & $\mathrm{t} \theta$ & $\mathrm{t} \theta / \theta$ & $\mathrm{t} \theta$ & $\mathrm{t} \theta$ & $\mathrm{t} \theta / \theta$ \\
\hline \multicolumn{16}{|c|}{ unreliable } \\
\hline & 1 & $\theta$ & $\theta$ & $\theta$ & $\theta$ & $\mathrm{d}$ & $\delta$ & $\delta$ & $\mathrm{d}$ & $\delta$ & $\mathrm{t} \theta$ & $\theta$ & $\theta$ & $\mathrm{t} \theta$ & $\theta$ \\
\hline & 2 & $\theta /$ bitfer & $\theta$ & $\theta / \int$ & $\theta$ & $\mathrm{d}$ & $\delta$ & $\mathrm{d}$ & $\mathrm{d}$ & d3 & $\mathrm{t} \theta / \mathrm{dz}$ & ts & ts & $\mathrm{t} \int$ & $\theta / \mathrm{t} \int$ \\
\hline & 3 & $\theta$ & $\theta$ & $\theta / \int$ & $\theta \int$ & $\mathrm{d}$ & $\mathrm{d}$ & $\mathrm{d}$ & $\mathrm{d}$ & $\delta$ & $\theta$ & ts & ts & $\mathrm{t} \theta$ & $\mathrm{t} \theta$ \\
\hline & 4 & $\theta$ & $\theta$ & $\theta / \int$ & $\theta$ & $\mathrm{d}$ & $\mathrm{d}$ & $\mathrm{d}$ & $\mathrm{d}$ & $\delta$ & $\mathrm{t} \theta$ & ts & $\theta$ & $\mathrm{t} \theta$ & $\theta$ \\
\hline \multicolumn{16}{|c|}{ semi-speakers } \\
\hline & 1 & $\theta$ & $\theta$ & $\theta$ & $\theta$ & $\mathrm{d}$ & $\delta$ & $\mathrm{d}$ & $\mathrm{d}$ & $\mathrm{d}$ & $\theta$ & $\theta$ & 0 & $\mathrm{t} \theta$ & $\mathrm{t} \theta$ \\
\hline & 2 & $\theta$ & $\theta$ & $\theta$ & $\theta$ & $\mathrm{d}$ & $\mathrm{d}$ & $\mathrm{d}$ & $\mathrm{d}$ & $\mathrm{d}$ & $\theta$ & ts & 0 & $\theta$ & $\theta$ \\
\hline & 3 & $\theta$ & $\theta$ & $\theta$ & $\theta$ & $\mathrm{d}$ & $\mathrm{d}$ & $\mathrm{d}$ & $\mathrm{d}$ & $\mathrm{d}$ & $\theta$ & ts & 0 & $\theta$ & $\theta$ \\
\hline & 4 & $\theta$ & $\theta$ & $\theta$ & $\theta$ & $\mathrm{d}$ & $\mathrm{d}$ & $\mathrm{d}$ & $\mathrm{d}$ & $\mathrm{d}$ & $\theta$ & $\theta$ & 0 & $\theta$ & $\theta$ \\
\hline
\end{tabular}

Table 5. Variations in the pronunciation of interdental fricatives and their substitutes

As expected, all reliable speakers pronounce the selected words with the phones $\theta$ and $\delta, 32$ whether isolated or contextualised (see Table 5). Perceptible differences concern only words in which a $t \theta$ is expected: it is heard consistently only in $t \theta u k a$ and $t \theta e s t a$, while $\theta$ can be heard in other words ( $\theta$ ukero, pran $\theta$ o, $\theta e n a$ ), particularly when put in a sentence.

The unreliable speakers' pronunciation of the words in question differs from that of the reliable (twice when $\theta$ is concerned, more often in the case of $\delta$ and $t \theta$ ). The older male subject professionally connected with northern Veneto substitutes $\theta$ with $t$ if the word is within a sentence: $t$ inkwe, tent. The younger one pronounces this phoneme as $\theta$ in all situations. The younger subject pronounces three words with $\delta$ ( $\delta$ endro, $v o \delta o$, pjan $\delta e$ ), and the other words with $d$; the older one pronounces the phoneme as $\delta$ only in one word (jenero 33 ), and in three words he replaces it with a dental plosive (dormir, vodo, vardar), and in one word his pronunciation is Italian (pjandbe). The difference is perceptible in words where a $t \theta$ is expected. The younger

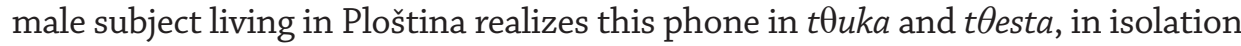
and in a phrase, while the older male subject does so only in $t \theta u k a$ when uttered alone. As for the other words, the younger male subject pronounces them with $\theta$, as would his older neighbours in Ploštine pronounce, while the older says tsukero, prantso, Aena and testa, as well as tena and dzuka if contextualised. This pronuncia-

32 Despite possible variations and differences in the speech of those subjects, all listeners agree that they hear

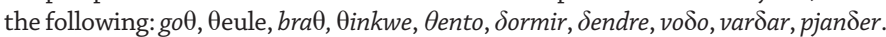

33 The correct form of this word in IVWS is $\delta$ endro, and not $\delta$ enero, which, apart from $\delta$, reflects the Italian variant, 'dzenero'. 
tion would be heard in northern Italian vernaculars or in the accepted Italian neostandard (Rohlfs 1966: 394, Canepari 1999, Berruto 1987).

The two unreliable speakers without active language contact with Italian speakers in Italy have the following pronunciations: Aena, Aeule and bra $\theta$. The male subject pronounces the other two words with $t$ ' if they are contextualised (tfinkwe, tfento). The female subject pronounces also tin kwe within a sentence, but keeps pronouncing $\theta e n t o$. These subjects pronounce the voiced equivalent, i.e. $\delta$, only in pjan $\delta e$, while in other cases they replace it with a dental plosive, so that we have dormir, dendro, vodo and vardar. The female subject pronounces the targeted $t \theta$ in $t \theta u k a$ and $t \theta e s t a$, and the male subject only in $t \theta e s t a$ (either isolated or contextualised). Both subjects say tsukero, and simplify t $\theta$ to $\theta: \theta u k a$ (only the ma/ $/{ }^{*}$ male), pran $\theta o$ and $\theta e n a$.

Four semi-speakers realize the voiceless interdental fricative: $\theta e n a, \theta e u l e, b r a \theta$, $\theta$ inkwe i $\theta$ ento. ${ }^{34}$ Except for the word $\delta$ endro, when pronounced by the oldest subject, in other cases $\delta$ is replaced with $d$ (dormir, vodo, vardar, pjande). The same subject has $t \theta$ in $t \theta e s t a$ and $t \theta e n a$, but replaces $t \theta$ with $\theta$ in $\theta u k a$ and $\theta u k e r o$. Two younger female subjects say tsukero, even though they were asked to repeat the word several times. They, as well as the male subject replace $t \theta$ with $\theta$ in other words: $\theta u k a, \theta e s t a$ and $\theta e n a$.

Although the phones $\theta, \delta, t \theta$, are still largely present in IVWS (respectively, $94.17 \%, 41.67 \%$ and $45.54 \%$, cf. Table 6 ), the results show that they all still prevail only in the speech of reliable subjects. However, $\delta$ has lost its domination, since it is replaced by $d$ (in 64 items, $53.33 \%$ ). The phone $t \theta$ is replaced mostly by $\theta$ (43 items, $38,39 \%)$ and, to a minor extent, by ts (12.5\%), $f^{\prime}(2.68 \%)$, and $d z(0.89 \%)$.

\begin{tabular}{|l|c|c|c|c|c|c|c|c|c|c|}
\hline $\begin{array}{l}\text { subjects } \\
\text { reliable }\end{array}$ & $\theta$ & $\mathrm{t} \int$ & $\delta$ & $\mathrm{d}$ & $\mathrm{d} 3$ & $\mathrm{t} \theta$ & $\theta$ & $\mathrm{ts}$ & $\mathrm{dz}$ & $\mathrm{t} \int$ \\
\hline & 10 & 0 & 10 & 0 & 0 & 10 & 0 & 0 & 0 & 0 \\
\hline & 10 & 0 & 10 & 0 & 0 & 8 & 2 & 0 & 0 & 0 \\
\hline & 10 & 0 & 10 & 0 & 0 & 8 & 2 & 0 & 0 & 0 \\
\hline & 10 & 0 & 10 & 0 & 0 & 8 & 2 & 0 & 0 & 0 \\
\hline \multicolumn{7}{|l|}{ unreliable } \\
\hline & 10 & 0 & 6 & 4 & 0 & 4 & 6 & 4 & 0 & 0 \\
\hline & 6 & 4 & 2 & 6 & 2 & 1 & 1 & 4 & 1 & 3 \\
\hline & 8 & 2 & 0 & 8 & 2 & 4 & 2 & 2 & 0 & 0 \\
\hline & 9 & 1 & 0 & 8 & 2 & 4 & 4 & 0 & 0 & 0 \\
\hline semi-speakers & 10 & 0 & 2 & 8 & 0 & 4 & 4 & 0 & 0 & 0 \\
\hline & 10 & 0 & 0 & 10 & 0 & 0 & 6 & 2 & 0 & 0 \\
\hline & 10 & 0 & 0 & 10 & 0 & 0 & 6 & 2 & 0 & 0 \\
\hline & 10 & 0 & 0 & 10 & 0 & 0 & 8 & 0 & 0 & 0 \\
\hline & 113,00 & 7,00 & 50,00 & 64,00 & 6,00 & 51,00 & 43,00 & 14,00 & 1,00 & 3,00 \\
\hline tot. item. & $94,17 \%$ & $5,83 \%$ & $41,67 \%$ & $53,33 \%$ & $5,00 \%$ & $45,54 \%$ & $38,39 \%$ & $12,50 \%$ & $0,89 \%$ & $2,65 \%$ \\
\hline
\end{tabular}

Table 6. Number of items per speaker pronounced with an interdental fricative or its substitute

34 It took some time to help them to remember the word go $\theta$. All declared that they did not know the word prant $\theta o$ (corresponding to prandzo in Italian) 


\section{Discussion}

The rather restricted number of subjects, as well as their dental status and age that negatively influence their self-perception and their creativity may put into question the value and the reliability of the obtained results. However, the results confirm earlier data (Deželjin 2015c), and it is clear that we still perceive the authentic phones described by Savi (1987), in particular 6 and $z$ (cf. Tables 1 and 2). These phones exist in the pronunciation of many reliable speakers, including those unreliable ones who have not been in contact with modern Italian variants. The unreliable speakers who have frequent contact with Italian speakers in Italy rarely utter 6 and $\mathrm{z}$ but substitute these types of voiceless and voiced sibilants with alveolar sibilants, i.e. $s$ and $z$. This fact is proof of language contact and the linguistic influence exercised by modern Italian vernaculars. The pronunciation of an unreliable speaker permanently living in Ploštine, who communicates on a daily basis with his fellow-villagers who are reliable speakers, supports this hypothesis, since in more controlled situations, such as the pronunciation of isolated words, he pronounces more alveolo-palatal voiceless and voiced sibilants ( 6 and $z$ ). Other unreliable speakers, who do not speak IVWS every day and are not influenced by modern Italian dialects, pronounce their sibilants prevalently as $\int$, instead of 6 , and as $z$ instead of 3 . While the outcome $\int$ may be due to the influence of Croatian, the majority language in the area, a significant presence of $\mathrm{z}$ contradicts to a certain extent the hypothesis of Croatian influence on IVWS35. This means that typical phones are preserved because of their peculiar and characteristic quality rather than because IVWS is used on a daily basis. The Croatian influence ${ }^{36}$ is affirmative in the semispeakers' pronunciation because this study, like the ones before it, ${ }^{37}$ confirms that alveolo-palatal sibilants have been lost, since semi-speakers pronounce these phonemes mostly as $\int$ and 3 . The prevalence of this pronunciation can be attributed to the fact that palatalised sibilants (postalveolar and alveolo-palatal) were characteristic of IVWS in the past. However, in the majority language, which shapes even the audial perception of the speakers of IVWS, there are only postalveolar sibilants, which, by analogy, spread and became dominant even in contexts where authentic IVWS does not have them (cf. the pronunciation riz, in regard to the Croatian riza, as well as IVWS $/ k o l a v s$. Croatian $/ k o l a)$.

Nevertheless, Lisac (2003) asserts that 6 and $\mathrm{z}$ are phones that exist in vernaculars spoken around Karlovac and in the area of western Slavonia where the Italian-speaking enclaves are situated.

36 It is valid especially for a heavy presence of $\int$, perceived either at the beginning of consonantal clusters in initial position or within a word in all Kajkavian dialects as well as in many Croatian vernaculars in western Slavonia and, to a certain extent, in standard Croatian (Zečević 2000).

37 The analyses of a large part of audial registrations confirm the difference in the pronunciation of reliable speakers and in that of semi-speakers. The following pairs of examples prove this (the first element stands for the reliable speaker's pronunciation and the second one for that of the semi-speaker): $60 \mathrm{on} /$ fon (< sono, 'I am'), noc/nof(< noce, 'wallnut'), cork/ fork (< sorgo,'sorghum'), ckriver/ fkriver (< scrivere, 'to write'); pizolar / pizolar (< dormicchiare, 'to have a nap') mezura /mezura (< misura, 'measure'), nozela / nozele (< nocciole, 'hazelnut'). 


\section{Conclusions}

This study showed that the phones which were recognized as characteristic in the past are still perceived in the pronunciation of a restricted number of reliable speakers. The loss of palatalised sibilants and interdental $\delta$ and $t \theta$ from the repertoire of unreliable speakers, or rather their substitution with, respectively, alveolar sibilants and dental plosives, is a wide-spread feature of the Italian variety spoken fluently by a number of people in the area, which differs from authentic IVWS. This trait of their pronunciation is one of the peculiarities typical of modern northern Italian vernaculars, and this may mean that present-day IVWS is no longer the language that a far greater number of people spoke thirty years ago. The unreliable speakers who have no contacts with northern Italian vernaculars do not show these characteristics so overtly, although postalveolar voiced sibilants and $\theta$, instead of $t \theta$ prevail in their pronunciation. Taking into account these facts, the first hypothesis has been partly confirmed. That is, while the phonetic inventory of reliable speakers does not present changes, my research shows that, apart from them, there are also speakers of a different language variant, one clearly influenced by modern northern Italian vernaculars.

When we take into consideration the contacts of the unreliable speakers with Italian vernaculars and of all my informants with Croatian-speaking people, changes in their pronunciation concerning the fusion of postalveolar and alveolopalatal sibilants into one type, especially among all semi-speakers, and the overall loss of $t \theta$, it is obvious that the second hypothesis has been confirmed, as well.

It must be added that the described phenomena and outcomes are due to the fact that singular phonetic realizations have never been completely functional. Therefore, the system, which has lacked speakers capable of supporting and cultivating phonetic differences, naturally aimed at simplification even if it has not been exposed to outer influences.

\section{References}

Berruto, Gaetano (1987). Sociolinguistica dell'italiano contemporaneo. Roma: Carocci. (2nd ed. 2012)

Brustolin, Mariantonia (1997). Italiani o Croati? Storia di una migrazione. Rasai del Seren del Grappa: Tipografia DBS

Canepari, Luciano (1999). Manuale di Pronuncia Italiana (MaPI). Bologna: Zanichelli

De Biasi, Antonella (1995). Associazione Emigranti e Lavoratori dell'Oltrardo detta »Della Bandiera«. Memorie. Lentiai: Grafiche Trabella

Deželjin, Vesna (2015a). Italofona enklava u zapadnoj Slavoniji između hrvatskoga i talijanskoga jezika. Udier, Sanda Lucija, and Kristina Cergol Kovačević, eds. Višejezičnost kao predmet multidisciplinarnih istraživanja. Zbornik radova s međunarodnoga znanstvenog skupa Hrvatskoga društva za primijenjenu lingvistiku održanoga od 25. do 27. travnja 
2014. godine u Zagrebu. Zagreb: Srednja Europa- Hrvatsko društvo za primijenjenu lingvistiku, 403-419

Deželjin, Vesna (2015b). The Italian Language Spoken by the Italians in Continental Croatia. Finotti, Fabio, and Marina Johnston, eds. L'Italia allo specchio. Linguaggi e idetità italiane nel mondo. Venezia: Marsilio Editori, 571-582

Deželjin, Vesna (2015c). La comunità italofona della Slavonia occidentale: un caso estremo di contatto interlinguistico. Consani, Carlo ed. Contatto interlinguistico fra presente e passato. Milano: LED, 421-441

Deželjin, Vesna (2017a). Jezično planiranje u odnosu na malu jezičnu zajednicu (primjer italofone jezične zajednice u zapadnoj Slavoniji). Rasprave: Časopis Instituta za hrvatski jezikijezikoslovlje 43(2): 331-342

Deželjin, Vesna (2017b). È possibile salvare una lingua minacciata: un'enclave italofona della Croazia continentale. Adamo, Stefano, and Claudio Nobili, eds. La capsula del tempo. Aspetti selezionati di lingua, letteratura e cultura italiana da conservare in prospettiva futura. Raleigh (CN): Aonia, 122-133

Fishman, Joshua A. (1991). Reversing Language Shift. Theoretical and Empirical Foundations of Assistance to Threathened Languages. Clevedon\&Philadelphia: Multilingual Matters

Francescato, Giovanni (1962). Il sistema dei suoni sibilanti nel dominio friulano. Revue de Linguistique 26(101-102): 51-70, http://doi.org/10.5169/seals-399290; http:// www.e-periodica.ch, also in Studi linguistici sul friulano. Firenze: Olschki, 1970: 99-117

Francescato, Giovani (1966). Dialettologia friulana. Udine, Società Filologica Friulana

Ladefoged, Peter (2003). Phonetic Data Analysis. An Introduction to Fieldwork and Instrumental Techniques. Blackwell Publishing

Lancerini, Silvio (1993). Vita e Cultura del Basso Cismon Bellunere. Dizionario del dialetto locale. Bassano del Grappa: Ghedina \&Tassotti Editori

Kliček, Josip (2009). Talijani u Slavoniji od 1880. do 2005. - Italiani in Slavonia dal 1880 al 2005. Grad Lipik: Zajednica Talijana Lipik - Città di Lipik: Comunità degli Italiani Lipik

Lisac, Josip (2003). Hrvatska dijalektologija I. Hrvatski dijalekti i govori štokavskog narječja i hrvatski govori torlačkog narječja. Golden Marketing - Tehnička knjiga, Zagreb

Nettle, Daniel, and Suzanne Romaine (2001). Voci del silenzio. Sulle tracce delle lingue in via di estinzione. Carocci: Roma.

Pasanac et alt. $=$ Pasanac, Ivan, Filip Škiljan, Lana Peternel, Jadranka Del Ponte, Zdenko Del Ponte, and Josip Del Ponte (2012). Talijani u Ciglenici. Zagreb: Športski kuglački klub

Rohlfs, Gerhardt (1966). Grammatica storica della lingua Italiana e dei suoi daletti. Fonetica. Torino: Einaudi

Rosalio, Maria Rita (1979). Studi sul dialetto trentino di Štivor (Bosnia). Firenze: La Nuova Italia, Firenze,

http://www.studiumanistici.unimi.it/files/_ITA_/Filarete/084.pdf Accessed March 10th 2018

Savi, Adriana (1987). Talijanski govor sela Ploštine kod Pakraca, B.A. thesis, University of Zagreb, Faculty of Humanities and Social Sciences

Sorianello, Patrizia (2002). I suoni fricativi dell'italiano fiorentino. Calamai, Silvia, and Chiara Finocchiaro, eds. Quaderni del Laboratorio di Linguistica della Scuola Normale Su- 
periore di Pisa. Nuova Serie 3/2002: 26-39 http://linguistica.sns.it/QLL/QLL02/Sorianello.pdf Accessed March 10th 2018

Tomasi, Giovanni (1983). Dizionario del dialetto bellunese arcaico. Con prefazione del prof. G. B. Pellegrini e con 53 tavole di Giuseppe Grava. Serie dizionari n. 2. Belluno: Istituto bellunese di ricerche sociali e culturali

Vince-Pallua, Jelka (2001). Od Italije do Male Italije - talijanske oaze u zapadnoj Slavoniji. Studia ethnologica Croatica 12/13: 233-247

Zamboni, Alberto (1974). Veneto, 5. Pisa: Pacini ed.

Zamboni, alberto (1988). Venezien - Veneto. Holtus, Günter, Michael Metzeltin and Christian Schmitt, eds. Lexikon der romanistischen Linguistik, Band/Volume IV: Italienisch, Korsisch, Sardisch. Italiano, Corso, Sardo, Areallinguistik IV/Aree linguistiche IV. Tübingen: Niemeyer, 517-538

\section{Slabljenje glasovnoga inventara ili promjene u glasovnom inventaru govornika talijanskoga idioma u zapadnoj Slavoniji}

U radu se proučavaju sibilantski i interdentalni frikativi uočeni u govoru pouzdanih ali i ostalih tipova govornika talijanskoga idioma u zapadnoj Slavoniji. Prisutnost i proizvodnju tih glasova valja promatrati $\mathrm{u}$ odnosu na isti tip glasova u bliskim talijanskim dijalektalnim govorima sjevernoga Veneta i naročito u arhaičnom govoru grada Belluna te u zapadnim furlanskim govorima. Prema prvoj postavljenoj hipotezi nedostatak podudarnosti u izgovaranju tih glasova kod svih govornika valja pripisati promjenama kojima je jezična zajednica izložena. Druga se hipoteza upire na tvrdnju da je nedostatak nekih glasova zamjetljivi učestao uglavnom među nepouzdanim govornicima i polugovornicima promatranoga idioma.

Rezultati pokazuju da ciljani glasovi još uvijek postoje uglavnom u govoru onih govornika koji nemaju znatnijih dodira s modernim talijanskim govorima; istodobno, pojedini se ciljani glasovi zamjenjuju sličnim glasovima koji postoje ili u suvremenim talijanskim govorima ili u govorima većinskoga hrvatskog jezika.

Keywords: sibilant and interdental fricatives, Italian vernacular of Western Slavonia, changes in phonetic inventory

Ključne riječi: sibilantski i interdentalni frikativi, talijanski idiom zapadne Slavonije, promjene u glasovnom inventaru 